\title{
Farm Women Empowerment through Secondary Agriculture
}

\author{
Deepa Indoria $^{1 *}$ and C.M. Balai ${ }^{2}$ \\ ${ }^{1}$ KVK, Chittorgarh, MPUAT, Udaipur, Rajasthan, India \\ ${ }^{2}$ KVK, Dungarpur MPUAT, Udaipur, Rajasthan, India \\ *Corresponding author
}

\section{Keywords \\ Vocational, Training, farm women, Rural, fruits, Vegetables, Value addition training knowledge skill adoption agriculture \\ Article Info \\ Accepted: \\ 22 July 2018 \\ Available Online: \\ 10 August 2018}

\section{A B S T R A C T}

Preservation and Value addition in agriculture predominantly offers a means to increase, rejuvenate and stabilize farm income. Krishi Vigyan Kendras is a premier training institute, signifying value addition training programme. The study reported here explored, to what extent the training programme of value addition had been changing participants perceived knowledge, acquisition of skills and adoption level Majority of the farming families in Rajasthan have marginal to small land holdings and their income is also very less. To enhance the income level and living standard of those farming families there is an urgent need to provide their family members particularly women an occupation based training like preservation of seasonal fruits and vegetables, which not only provides them an occupation but also develop entrepreneurial characteristics amongst them. These trainings are also useful for rural women as they can add more value to the seasonal fruits and vegetables by making Pickle, Murabbaa, Chutney, Jam, Sharbat etc. These trainings enhance their family income by around 30-40 thousands /annum. They fetch more prices of their raw produce after processing, moreover during peak production times. Instead of direct marketing, they did value addition of their produce and then sell them, it increased the value and prices of their products by many folds. After giving them training they are motivated to go for self-marketing of their produce at domestic and village level. About 200 farm women have received training in the year 2016-17 and nearly 64 of them have adopted this at commercial and domestic level. These trainees were imparted training on preparation of Pickles, Jam, Chutney, Murabaa, and Squashes etc. They were highly satisfied with the training they received. Similar way these trainings can change the life style and income level of farming families comprehensively.

\section{Introduction}

The results exemplified the impact of value addition training in instilling positive orientation in terms of the magnitude of perceived knowledge, acquisition of skills and adoption levels. Moreover, the findings of the study conclude: (i) education level of participants, post-harvest knowledge and attitude towards value addition are contributing factors for improving the positive impact of training, (iii) more feasible strategies (e.g. increasing training duration) are required for improving participant's skills and (iv) several interventions (e.g. generating new market) of the State Government are needed for increasing the adoption level. The study recommends the policy should 
emphasize: increasing agricultural and postharvest knowledge content in formal education, developing and manifesting a positive attitude and improving skills of potential producers, as well as improving producer's access to resources Family farming is one of the most predominant forms of agriculture world-wide, both in developing and in developed countries. In India, there are distinct male and female roles in the rural economy. Women and girls engage in a number of agro-oriented activities ranging from seedbed preparation, weeding, and horticulture and fruit cultivation to a series of post-harvest crop processing activities like cleaning and drying of vegetables, fruits and nuts for domestic use and for marketing.

A disproportionate number of those dependent on land are women: $58 \%$ of all male workers and $78 \%$ of all female workers, and $86 \%$ of all rural female workers are in agriculture. Female-headed households range from 20\% to $35 \%$ of rural households (widows, deserted women as well as women who manage farming when their men migrate). Although the time devoted by both women and men in agricultural activities may, in several communities and agricultural situations, be taken to be almost equal, women are dominant within the domestic tasks. Rural Indian women are extensively involved in agricultural activities, but the nature and extent of their involvement differs with variations in agro- production systems (Nagaraja, 2013). There are community-based differences regarding women's participation in agriculture, therefore location, cropping patterns, ethnic affiliation and economic and educational background also have implications for the specific division of labor within a given family unit. In addition to their role in agricultural production, women are gainfully employed in agric- based allied activities like dairying, animal husbandry, poultry, goatery, rabbit rearing, beekeeping, floriculture, horticulture, fruit preservation, post-harvest technology, value added food products, etc.

There is need to design programmes which could gainfully utilize the services and skills of women in relation to their involvement in agric-based allied activities. This would also help in generating self-employment and rural entrepreneurship. Some of the ventures would include agric-service centers' sale of quality seeds and other agricultural inputs; advisory services and consultancy; village-level marketing; multipurpose warehouses and controlled atmosphere storage; hiring of implements; micro propagation; hatcheries for fishery; production of bio-fertilizers; biocontrol agents; beekeeping; livestock feeding and health management and artificial insemination; value addition to fruits and vegetables, food processing, food preservation and testing units; post-harvest management units; social agro-forestry; agric-horticulture; cultivation and management of medicinal and aromatic plants; utilization of crop residues; mushroom cultivation; poultry; piggery; goatary; agric-based handicrafts; child health care centers; use of renewable and unconventional sources of energy; low cost household equipments and appliances, value addition etc.

Entrepreneurship skills can help in building confidence and self-awareness through income generation. Various activities can be taken up by rural women for income generation while being at home and by organizing themselves in Self Help Groups (SHGs) (Anonymous, 2001). SHG is a small voluntary association of women, preferably from the same socioeconomic background. It has transferred the real economic power in the hands of women and has considerably reduced their dependence on men. This has helped in empowerment of women and building selfconfidence (Ghadoliya, 2005). Usually, women's representation is greater in allied 
agriculture than in grain production, and poor households require the greater involvement of women in income-generating activities than financially stable ones. Therefore, to enhance the income level and living standard of those farming families there is an urgent need to provide their family members particularly women an occupation based training like preservation of seasonal fruits and vegetables, which not only provides them an occupation but also develop entrepreneurial characteristics amongst them.

\section{Materials and Methods}

All Krishi Vigyan Kendras under MPUAT Udaipur, organized short term, long term and vocational training courses for farm women and rural school dropouts girls. The study was conducted in Krishi Vigyan Kendra, Chittorgarh. A list of farm women and rural girls who had received vocational trainings in the year of 2016-17 was procured from the KVK, Chittorgarh.

Total 200 farm women and rural girls were received vocational trainings. The data were collected by interviewing the farm women and rural girls personally with the help of structured interview schedule. The data were tabulated on the master sheets for further processing and analyzed with the help of the necessary statistical techniques.

\section{Results and Discussion}

\section{Socio economic profile}

Data in Table 1 reveals that majority of the farm women i.e. 53.00 per cent belongs to 25 35 years of age group and 21.00 per cent of them were from age group of above 35 years. Most of the farm women were married (76.00 $\%)$ and belonged to joint family $(89.00 \%)$. Nearly 60.00 per cent of the farm women had more than Rs. 3, 00,000 of annual income.

\section{Training received by farm women}

All the respondents received different vocational trainings from KVK Chittorgarh. Data in Table 2 depicted that More than half of the farm women 55.00 per cent received vocational training on preservation of seasonal fruits and vegetables, followed by training on decorating fabric with painting, printing and dyeing of cloth $(35.00 \%)$ and making furnishes for home and preparation of toys and games for children (5.00\% each).

\section{Adoption of enterprise}

After receiving vocational trainings from KVK farm women started some income generating activities as small scale enterprises for their financial growth.

A group of 28 farm women started making of Squashes and Sharbat followed by 25 farm women who started making of Pickles, Jam and Sharbat at small scale (Table 3).

Chutneyes and Murabbaa were made by a group of 22 farm women whereas, a group of 13 farm women started making of pickles. A group of 10, 9, and 7 farm women started making Sharbatas, Chutneyes and jam respectively.

\section{Increase in income}

All the farm women were very happy and satisfied with their own enterprise they have started. Nearly 60.00 per cent of farm women were belong to medium i.e. Rs. 1, 00,000 to 3, 00,000 categories before the training but after receiving training their annual family income has been increased by Rs. 20,000-50,000.

The farm women whose family annual income was about Rs. 3,00,000 or more than this earned extra Rs. 50,000 annually. 
Table.1 Socio economic profile of the respondents $(n=200)$

\begin{tabular}{|c|c|c|c|c|}
\hline S. No. & \multicolumn{2}{|c|}{ Particulars } & Frequency (f) & Percentage (\%) \\
\hline \multirow{3}{*}{1.} & \multirow{3}{*}{ Age } & $20-25 \mathrm{yrs}$ & 52 & 26.00 \\
\hline & & $25-35$ yrs & 106 & 53.00 \\
\hline & & $25-35 \mathrm{yrs}$ & 106 & 53.00 \\
\hline \multirow[t]{2}{*}{2.} & \multirow[b]{2}{*}{ Marital status } & Unmarried & 152 & 76.00 \\
\hline & & Married & 48 & 24.00 \\
\hline \multirow[b]{2}{*}{3.} & \multirow[b]{2}{*}{ Family type } & Nuclear & 22 & 11.00 \\
\hline & & Joint & 178 & 89.00 \\
\hline \multirow[t]{3}{*}{4.} & \multirow{3}{*}{$\begin{array}{l}\text { Annual income } \\
\text { (Rs.) }\end{array}$} & $>1,00,000$ & 39 & 19.50 \\
\hline & & $1,00,000-3,00,000$ & 118 & 59.00 \\
\hline & & $3,00,000$ and above & 43 & 21.50 \\
\hline
\end{tabular}

Table.2 Distribution of respondents on the basis of training received from KVK Chittorgarh $(n=200)$

\begin{tabular}{|l|l|l|l|}
\hline S/No. & Title of the training & Frequency (f) & Percentage (\%) \\
\hline $\begin{array}{l}\text { 1. } \\
\text { Decorating fabrics with printing tie and } \\
\text { dye and fabric painting }\end{array}$ & 70 & 35.00 \\
\hline $\begin{array}{l}\text { Preservation of seasonal fruits and } \\
\text { vegetables }\end{array}$ & 110 & 55.00 \\
\hline 3. & $\begin{array}{l}\text { Making furnishing for homes } \\
\begin{array}{l}\text { Preparation of toys and games for } \\
\text { children }\end{array}\end{array}$ & 10 & 5.00 \\
\hline 4. & 10 & 5.00 \\
\hline
\end{tabular}

Table.3 Distribution of respondents on the basis of their adoption of enterprise $(n=200)$

\begin{tabular}{|c|c|c|c|}
\hline S/No & Particulars & $\begin{array}{l}\text { Frequency } \\
\text { (f) }\end{array}$ & Percentage $(\%)$ \\
\hline 1. & Making of pickles & 13 & 6.50 \\
\hline 2. & Making of Pickles, Jam and Sharbat & 25 & 12.50 \\
\hline 3. & Making of Jam & 7 & 3.50 \\
\hline 4. & Making of Chutneyes & 9 & 4.50 \\
\hline 5. & Making of Chutneyes and Murabbaa & 22 & 11.00 \\
\hline 6. & Making of Squashes and Sharbat & 28 & 14.00 \\
\hline 7 & Making of Sharbatas & 10 & 5.00 \\
\hline 8 & Not adopted & 86 & 43.00 \\
\hline
\end{tabular}



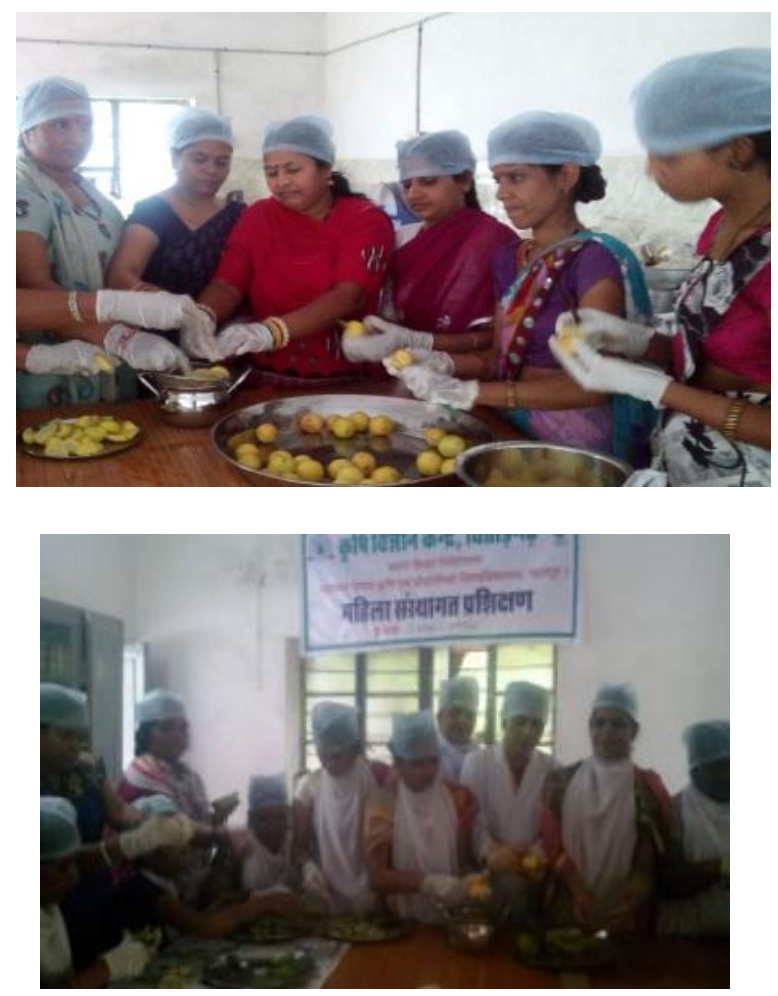

Vocational training can play a key role in helping girls get jobs and become selfdependent. Other vocational training programmes help girls build a wide set of soft skills, and increase their family income. These trainings helping them to gain financial independence (Dunning, 2013).

Woman has been as important as man. In fact, the status, employment and work performed by women in society are the indicators of a nation's overall progress. Without the participation of women in national activities, the social, economical or political progress of a country will be stagnated. Rural women can play a significant role by their effectual and competent involvement in entrepreneurial activities. They have basic indigenous knowledge, skill and potential and resources to establish and manage enterprise. Income generating activities are effective instrument of social and economic development to generate employment for a number of farm women within their own social system and
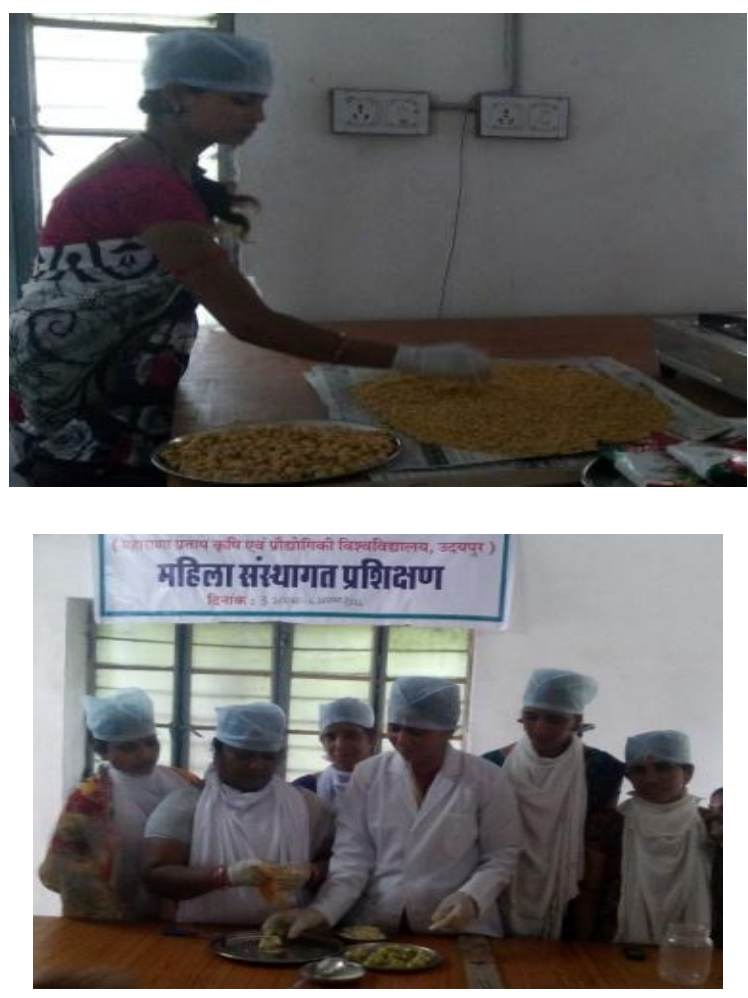

best tool for rural women as it adds to the family income. A successful intervention for empowering women necessitates several elements - an important one is imparting of new skills:: the consequence of women assuming new roles is also support through training for enabling them to perform these roles. Trainings have to make women recognize clearly how society structures their perceptions. The training programme must promote critical analysis in women and encourage them to think independently and challenge unequal gender relations and exploitation.

\section{References}

Anonymous, 2008. Strengthening research stations non-farm sectors through technological at the University of Agricultural Sciences, interventions with emphasis on primary value Bangalore-65, Rashtriya Krishi Vikas Yojana. The addition. Policy Paper No. 
37, New Delhi, India. Government of Karnataka.

Anonymous. National academy of agricultural sciences, India. 2001, 2-4.

Danielson, R. and D. Park, 2001. Valueadded, on Washington. farm processing, Case Study 11, North Dakota State 5. Gandhi, V., G. Kumar and R. Marsh, 2001. University, USA. Agro-industry for rural and small farmer.

Dunning D. Vocational training for young women: what works and what doesn't, Guardian Professional, UK, 2013.

Francis, A., 2006. Value-added agriculture: from our 13. Mrema, G.C. and R.S. Rolle, 2002. Status of the futures on the table, A Publication of ATTRApostharvest sector and its contribution to National Sustainable Agriculture Information Service. agricultural development and economic growth.

Ghadoliya MK. Empowering women through self -help groups: Role of distance education. https://www.col.org/pcf3/ Papers/PDFs/Ghadoliya_MK.pdf. 16, December, 2016.

Lee, J.H., D. Henneberr and D. Pyles, 1991. An Mori, Y. Hayashi, T. \& Highley, E. (Eds), Value analysis of value-added agricultural exports to Addition to Agricultural Products- Towards increase middle-income developing countries: the case of of farmers' income and vitalization of rural economy. wheat and beef products, Southern Journal of Proceedings of the 9th JIRCAS International Agricultural Economics, Dec. 1991.

NAAS (National Academy of Agricultural Sciences), development: issues and lessons from India. 2005. Redefining agricultural education and extension International Food and Agribusiness Management system in changed scenario. Policy Paper No. 31, Review, 2: 331-344. NAAS, New Delhi, India.
Nigeria. Growth in high-value agriculture in Asia and the Extension Service, Institute of Food and Agriculture.

Nagaraja B. Empowerment of women in India: A critical analysis. Sri Venkateswara University, College of Arts Sri Venkateswara University TIRUPATI, 2013.

NSSO (National Sample Survey Organisation) 2005. Cafeteria for women in agriculture, NCAP Working Situation assessment survey of farmers: Access to Paper No.4, National Centre for Agricultural modern technology for farming. National sample Economics and Policy Research, New Delhi, India.

survey, 59th round (January-December 2003). Report19. NCAP (National Centre for Agricultural Economics 499: (59/33/2). New Delhi. and Policy Research), 2005. Impact of agricultural.

Sen, A. and Himanshu, 2005. Poverty and inequality research: post-green revolution evidence from India, in India: getting closer to the truth. Economic and (Eds. P K Joshi, Suresh Pal, P S Birthal and M C S Political Weekly, January. Bantilan), New Delhi, India.

Shekara, P.C., 2001. Private extension in 20. Deshpande, C.S., 2005. Contracting framing as means India: myths, realities, apprehensions and of valueadded agriculture, Occasional paper approaches, National Institute of Agricultural Department of Economic Analysis and Research, Extension Management Rajendra Nagar, Hyderabad, National Bank for Agriculture and Rural India. Development, Mumbai.

Reddy, C.S. and S. Manak, 2005. Self-help groups.

Progressive Farmer, 2000. Value-added concept helps national commission on 
small farms: a report of the farmers. Birmingham, AL: Progressive Farmer. USDA National Commission on Small Farms.

Singh, R.B., P. Kumar and T. Woodhead, 2002. World Appl. Sci. J., 22 (10): 1401-1411, 20131410

Sulaiman, R.V., T. Jafry and M.S. Asok, 2003.

Symposium, Tsukuba, Japan, 16-17 October, 4. Volkmer, Harold, L., M. Macdonald and C. Curtter, pp: 13-20. 1998.

USDA, 2010. A national information resource for Smallholder farmers in India: food security and value added agriculture, US Department of agricultural policy, FAO of the United Nations, Agriculture, Rural Business Development, Regional Office for Asia and the Pacific Bangkok, Washington, DC. Thailand.

\section{How to cite this article:}

Deepa Indoria and Balai, C.M. 2018. Farm Women Empowerment through Secondary Agriculture. Int.J.Curr.Microbiol.App.Sci. 7(08): 4131-4137.

doi: https://doi.org/10.20546/ijcmas.2018.708.430 